Plant Production Science

http:/www.journals.zu.edu.eg/journalDisplay.aspx?Journalld=1\&queryType=Master

\title{
DETERMINATION OF GENETIC DIVERSITY IN SESAME
}

\author{
Khames A. Mourad ${ }^{1}$, Rasha Y.S. Abd El-Khalek ${ }^{2 *}$ and Nemat A.Naguib ${ }^{2}$ \\ 1. Oil Crops Dept., Field Crops Res. Inst., Agric. Res. Center., Giza, Egypt \\ 2. Seed Technol. Res. Dept., Field Crops Res. Inst., Agric. Res. Cent., Giza, Egypt
}

\section{Received: 13/02/2019 ; Accepted: 08/04/2019}

\begin{abstract}
The present investigation was carried out to identify eleven sesame lines during two successive seasons $\left(2016\right.$ and 2017). The phenotypic variance $\left(\sigma_{p}^{2}\right)$ was greater than the corresponding variance for all studied traits except capsule thickness. The genotypic variance and phenotypic variance values for number of capsules/plant and oil yield/fad., were high over the two years. High broad-sense heritability accompanied with high genetic advance was recorded for No. of branches/ plant, seed yield/plant and seed yield/fad. Five SSR primers were used for fingerprinting of the eleven sesame genotypes generated 19 bands, 10 of them were polymorphic with $53 \%$ polymorphism, N.A $A_{554}$ produced one band negative marker in primer SSR1. Line 59-3-1 produced two band markers, one of them negative marker in primer SSR1 and the other positive marker in primer SSR5, while Line 82-7 produced one band positive marker in primer SSR5.
\end{abstract}

Key words: Sesame (Sesamum indicum L.), morphological characters, simple sequence repeat (DNA-SSR).

\section{INTRODUCTION}

Sesame (Sesamum indicum L.) is important oil seeds crops and is widely cultivated in Africa and Asia. It is the queen of high quality vegatable oils for human consumption as it contains high levels unsaturated fatty acids and antioxidants e.g. sesamol, sesamin, sesamolin and sesaminor (Nupur et al., 2010). The genetic divesity have been mainly depended on agro-morphological traits and present of the gentic variability in gene pool to improve yield and yield contributing traits. The effectiveness of selection depends on genetic variabilty, heritability of traits and nuture of gene action. Genetic diversity parameters in sesame were studied by many sesame investigators i.e. Banerjee and Kole (2006), Laurenthin and Korlovsky (2006) and Fazal et al. (2011) who reported that genetic variability among indian sesame accessions was very high based on morphological and molecular markers. Spandana et al. (2011) indicated that among the thirteen traits studied, seed yield was higher in genotypic coefficient of variability (GCV), followed by

\footnotetext{
* Corresponding author: Tel. : +201142437717

E-mail address: ryabdelkhalek@gmail.com
}

nodes/main stem, meanwhile, seed weight exhibited lower estimates of GCV. Number of breanches/plant registered the highest PCV, while seed weight was the lowest in respect to PCV. The difference between the PCV and PGC values for nodes/main stem was high indicating the influence of environment on these traits. However, the narredge difference between the PCV and GCV values for other traits, indicating minimum effect of environment. High genotypic coefficient of variability and phenotypic coefficient of variability were observed for number of branches/plant, number of capsules/plant, and seed yield/plant. Meanwhile, high heritability with high genetic advance as percent of mean were observated in number of branches/plant, number of capsules/plant and seed yield/plant (Revathi et al., 2012). Simple sequence repeats are widely used in plant molecular genome coverage Powell et al. (1996) showed that SSR marker development in sesame are limited and most work involved the development of genie SSRs from expressed sequence tag (EST), compared to more than 1000 SSR loci mapped in other oil seed crops like soybean as revealed 
by Song et al. (2004). Spandana et al. (2012) used 111 SSR in sesame and recognized 156 EST SSR along with primer sequence information from 16.619 EST mined from genbank. The recent advances madein the development of molecular tools in sesame are encouraging, however to make use of a high density molecular linkage map, the member of available SSR markers is further research efforts are needed to develop sesame-specific markers in abundance to make use of the variability present in the sesame germplasm. There for SSR markers would be one of the useful molecular markers in sesame genetic diversity analyses and in marker assisted breeding program, Zhang et al. (2010) and Surapaneni et al. (2014) reported that SSR markers are appropriate for evaluation of genetic diversities in sesame and also concluded that extensive genetic divergence existed among indigenous and exotic collections of sesame. Park et al. (2013) reported that 41 genotype specific alleles were identified for 12 of 14 SSR markers. The objectives of the present study was to study the phenotypic variability, sesame seed quality by using some vigor and viability tests and to determine the major chemical composition of seed and fatty acid composition of oil. Also to estimate the genetic purity of ten promising sesame lines and commercial cultivar, in order to obtain reliable information for recommending desired genotypes and making decisions concerning the proper breeding method for improving yield and yield components.

\section{MATERIALS AND METHODS}

\section{Field Trail}

The materials under study consisted of commercial sesame cultivar Shandwell 3 and ten sesame genotypes namely, N.A 554 , Line 59-3-1, Line 88-2, Line 89-26, Line 106-2, Line 82-7, Line $111-8, N . A_{542}, N . A_{558}$, and N.A $A_{432}$. The pedigree of these genotypes is shown in Table 1 . The experiments were carried out during the summer seasons of 2016 and 2017 at Giza Research Station (ARC), Egypt. The expirement was laid out using randomized complete block design with three replications. Each entry was grown in a plot consisting of four redges, 4 meters long, distance between redges was $50 \mathrm{~cm}$ and distance between plants within the redge was $20 \mathrm{~cm}$, with one plant left per hill after thining. The culture practices were done according to recmmended methods. The observations were recorded on ten randomely selected plants per plot for the following agronomic characters:

\section{Morphological Traits}

The following morphological traits were measured based on individual plants i.e. plant height $(\mathrm{cm})$, lenght of fruting zone $(\mathrm{cm})$, number of branches/plant, number of nodes / plant, internode length $(\mathrm{cm})$, stem thicknes $(\mathrm{cm})$, number of capsules/plant, capsule lenght $(\mathrm{cm})$ and capsule thicknes (cm).

\section{Yield parameters}

At harvest, seed yield/plant (g), seed index (g), seed yield/fad., (ard) and oil yield/fad., (kg) were determined.

\section{Laboratory Tests}

\section{Germination test}

Normal seedlings were counted acorrding to the international rules of ISTA (1993). Germination percentage was calculated using the formula by Krishnasamy and Seshu (1990).

\section{Seedling evaluation}

Normal seedlings were used for seedling evaluation according to the rules of the Assocition of Offecial Seed Analysis (AOSA, 1983). Seedling, shoot and root lenght were measured after six days of germination test. The shoots and roots were also dried at $70^{\circ} \mathrm{C}$ for 72 $\mathrm{hr}$. Seedling vigor index was calculated according to formula describe by ISTA (1985).

\section{Chemical composition}

Sampels of about $50 \mathrm{~g}$ air dried seeds of eash genotype were rondomly chosen from three replications and fine ground for estimating chemical composition. Total nitrogen was determined using kjeldhel method AOAC (2000).

\section{Stastical Analysis}

Analysis of variance was calculated for data according to Mather and Jinks (1982). According to homogenity test, the results of 2016 and 2017 did not differ significant, so the combined analyses of the two seasons were conducted. The phenotypic and genotypic variances and their coffecients of variation and 
Table 1. Pedigree and origin of eleven seseam genotypes

\begin{tabular}{|c|c|c|}
\hline Genotype & Original & Pedigree \\
\hline Shandwell 3 & Egypt & Commercial cultivar \\
\hline Line 88-2 & Egypt 1974 & Selected from local $25^{*}$ N.A.126-19 \\
\hline N.A $\mathbf{A 5 4}_{54}$ & FAO 1983 & - \\
\hline Line 59-3-1 & Egypt 1968 & Selected from local S14/18*Mahly \\
\hline Line 89-26 & Egypt 1974 & Selected from local Local $25 *$ N.A129 \\
\hline Line 106-2 & Egypt 1978 & Selected from local N.A.114*N.A. 247 \\
\hline Line 82-7 & Egypt 1972 & Selected from local N.A.114*Giza25 \\
\hline Line 111-8 & Egypt 1981 & Selected from local B32*N.A.32 \\
\hline $\mathbf{N A}_{542}$ & FAO 1983 & - \\
\hline $\mathbf{N A}_{558}$ & Barazil 1982 & - \\
\hline $\mathbf{N A}_{432}$ & USA 1976 & - \\
\hline
\end{tabular}

broadnsense hertability for each trait were calculated according to Singh and Chaudhry (1985) as follow:

Genotypic variance $\left(\sigma_{9}^{2}\right)=\left(\mathrm{Ms}_{9}-\mathrm{Ms}_{\mathrm{e}}\right) / \mathrm{r}$

Phenotypic variance $\left(\sigma_{\mathrm{p}}^{2}\right)=\sigma_{\mathrm{g}}{ }_{\mathrm{g}}+\sigma_{\mathrm{e}}^{2}$

Where :

Mss: is an estimate of mean square of tested accession,

$\mathrm{Ms}_{\mathrm{e}}$ : is an estimate of mean square of error, and $r$ refers to the number of replications,

$\sigma_{\mathrm{e}}^{2}$ : is an error of variance.

Genotypic coefficient of variance (GCV) and phenotypic coefficient of variance (PCV) were caculated as fallow:

$\sigma_{\mathrm{g}}^{2}, \sigma_{\mathrm{ph}}^{2}=$ Genotypic and phenotypic variation respectively and $\mathrm{x}$ grand mean $(\mathrm{GA} \%)=\sigma_{\mathrm{ph}}^{2} \times 100$

Broad sense heritability and genetic advance as percent of mean (GA\% of mean) for each trait were computed according Allard (1960) as follow:

$$
\mathrm{h}_{\mathrm{b}}^{2}=\sigma^{2}{ }_{\mathrm{g}} / \sigma_{\mathrm{ph}}^{2} \times 100
$$

The expected genetic advance $(\mathrm{GA})=\mathrm{k} \mathrm{x} \sigma^{2}{ }_{\mathrm{ph}} \mathrm{x} \mathrm{h}_{\mathrm{b}}{ }_{\mathrm{b}}$. Genetic advance as (\%) of the mean $=\mathrm{GA} / \mathrm{x}^{-} \times$ 100 . Where $\mathrm{K}$ selection defferential at $5 \%$ selection intensity $(\mathrm{K}=2.06)$ and $\mathrm{x}^{-}=$grand mean.
Genotypic and phenotypic correlations between traits were calculated according Miller et al. (1958).

\section{Molecular Markers}

\section{SSR-PCR analyses}

Five SSR primers were used to evaluate the eleven sesame genotypes as shown in Table 2 .

\section{DNA extraction}

For genomic DNA isolation, seeds of each of the sesame genotypes were germinated and gredgen to the four-leaf stage. The seedlings were used for DNA extraction by DNeasy plant minikit (Quigen Inc., Cat.no. 69104, and USA). The DNA concentration of the final samples was measured by ultraviolet (UV) spectrophotometer at $260 \mathrm{~nm}$. The integrity of the DNA was checked out by electrophoresis in a $2 \%$ agarose gel in TAE buffer.

\section{Polymerase chain reaction (PCR) conditions}

DNA amplification was carried out in PCR tubes containing $25 \mu \mathrm{l}$ reaction mixture, having $1 \mu \mathrm{l}$ template DNA, $1 \mu \mathrm{l}$ SSR primer, $15 \mu \mathrm{l}$ of add $\mathrm{H}_{2} \mathrm{O}$ and $7 \mu \mathrm{l}$ PCR mix. Amplification was carried out in a PTC- 200 thermal cycler (MJ Research, Watertown, USA) programmed as follows: The temperature profile consisted of an initial denaturation step of DNA at $94^{\circ} \mathrm{C}$ for $2 \mathrm{~min}$., 
Table 2. Name and sequence of SSR primers which were used for SSR-PCR analyses

\begin{tabular}{ll}
\hline Primer name & Sequence \\
\hline Sa07- SSR 1 & Forward 5'TCA TAT ATA AAA GGA GCC CAA C3' \\
& Reverse 5'GTC ATC GCT TCT CTC TTC TTC3' \\
Sa08- SSR 2 & Forward 5'GGA GAA ATT TTC AGA GAG AAA AA C3' \\
& Reverse 5'ATT GCT CTG CCT ACA AAT AAA A 3' \\
Sa72- SSR 3 & Forward 5'GC AGA GTT CCG TTC TTG 3' \\
& Reverse 5'AGT GCT GAA TTT AGT CTG CAT AG 3' \\
Sa108- SSR 4 & Forward 5'CCA CTC AAA TTT TCA CTA AGA A 3' \\
Sa123- SSR 5 & Reverse 5'TCG TCT TCC TCT CTC CCC 3' \\
& Forward 5'GCA AAG ACA TGC ATC CCT 3', \\
& Reverse 5'GCC CTG ATG ATA AAG CCA 3' \\
\hline
\end{tabular}

followed by 35 cycles: $94^{\circ} \mathrm{C}$ for 45 sec., $57-$ $65^{\circ} \mathrm{C}$ for $1 \mathrm{~min}$, and $72^{\circ} \mathrm{C}$ for $1 \mathrm{~min} 30 \mathrm{sec}$. Annealing temperatures were optimized individually for each SSR (listed in Table 2). After the final cycle, samples were incubated at $72^{\circ} \mathrm{C}$ for $10 \mathrm{~min}$., to ensure complete extension.

\section{Gel electrophoresis}

Gel electrophoresis was applied according to Sambrook et al. (1989). The run was performed for one hour at 80 volt in pharmacia submarine $(20 \times 20 \mathrm{~cm})$. Bands were detected on UVtransilluminator and photographed by Gel documentation 2000, Bio- Rad. Fragment size of simple sequence repeat (SSR) was estimated from the gel by comparison with the $100+1.5 \mathrm{~kb}$ ladder marker. The bands were recorded as either present or absent into a database of "+" "and "_-"

\section{Data Analysis}

The data of PCR systems were analyzed to detect the similarity matrices using Gel/works 1D- advanced software UVP-England program. The relationships among different eight genotypes as reveled by dendrograms resolved using SPSS Windows (Version 16) program were estimated. Possible molecular markers for different qualitative and quantitative characteristics were detected for subsequent linkage and genome analyses.

\section{RESULTS AND DISCUSSION}

\section{Agronomic Traits}

Results given in Table 3 show mean performance of eleven sesame genotypes for some morphological traits. Significant differences were recorded among genotypes for agronomic traits i.e. Plant height, lenght of fruting zone, No. of branches/plant, No. of nods/plant internod length, stem thicknes, No. of capsules/plant and capsule lenght. Plant height varied from 167.2 $\mathrm{cm}$ to $233.3 \mathrm{~cm}$ with a mean of $206.6 \mathrm{~cm}$. The tallest genotype was N.A $\mathrm{A}_{588}$, while N.A $\mathrm{A}_{54}$ was the shortest one.

With respect to lenght of fruting zone, it ranged from $101.7 \mathrm{~cm}$ for N.A A $_{54}$ to $162.8 \mathrm{~cm}$ for N.A 558 . Number of branches/plant exhibited wide range from 1.3 to 7.7 . Genotypes line $88-8$, line 59-3-1, line 106-2, line 82-2, line111-8 and N.A 558 had a great number of branches/plant, in contrast, Shandwell 3, N.A $A_{432}$ had low number of branches/plant Number of nods/plant ranged from 30.5 to 42.0. Line 89-26 and Line 111-8 had the greatest number of nods/plant mean while, Line 88-8 and Line 111-8 had the lowest number of nods/plant With respct to internod lenght, it ranged from 8.1 to $12.2 \mathrm{~cm}$ with mean $10.3 \mathrm{~cm}$. Shandwell 3 had significantly the largest internod lenght compared to the other genotypes, while, N.A $\mathrm{A}_{554}$ and line 106-2 were 
Table 3. Mean performance and range for some morphological traits for eleven sesame genotypes (over two years)

\begin{tabular}{lccccccccc}
\hline Genotype & $\begin{array}{c}\text { Plant } \\
\text { height } \\
\text { (cm) }\end{array}$ & $\begin{array}{c}\text { Length of } \\
\text { fruting } \\
\text { zone }\end{array}$ & $\begin{array}{c}\text { No. of } \\
\text { branches/ } \\
\text { plant }\end{array}$ & $\begin{array}{c}\text { No. of } \\
\text { nods/ } \\
\text { plant }\end{array}$ & $\begin{array}{c}\text { Internod } \\
\text { length } \\
\text { (cm) }\end{array}$ & $\begin{array}{c}\text { Stem } \\
\text { thicknes } \\
\text { (cm) }\end{array}$ & $\begin{array}{c}\text { No. of } \\
\text { capsules/ } \\
\text { plant }\end{array}$ & $\begin{array}{c}\text { Capsule } \\
\text { length } \\
\text { (cm) }\end{array}$ & $\begin{array}{c}\text { Capsule } \\
\text { thicknes } \\
\text { (cm) }\end{array}$ \\
\hline Shandwell 3 & 206.3 & 135.5 & 1.3 & 35.2 & 12.0 & 2.7 & 187.3 & 2.6 & 0.77 \\
Line 88-8 & 195.5 & 124.8 & 7.0 & 30.5 & 10.3 & 2.3 & 238.3 & 3.5 & 0.68 \\
N.A55 & 167.2 & 101.7 & 3.2 & 32.7 & 8.7 & 2.3 & 163.3 & 3.5 & 0.75 \\
Line 59-3-1 & 221.2 & 146.2 & 7.7 & 35.2 & 10.8 & 2.8 & 200.5 & 3.5 & 0.73 \\
Line 89-26 & 215.5 & 147.2 & 5.0 & 42.0 & 10.9 & 2.7 & 241.3 & 3.1 & 0.74 \\
Line 106-2 & 217.2 & 133.8 & 7.3 & 34.6 & 9.1 & 2.7 & 192.2 & 3.4 & 0.72 \\
Line 82-7 & 225.3 & 147.3 & 7.3 & 38.6 & 10.3 & 3.0 & 222.7 & 3.3 & 0.78 \\
Line 111-8 & 211.8 & 141.8 & 7.2 & 40.0 & 12.2 & 2.7 & 202.1 & 3.5 & 0.73 \\
N.A542 & 173.0 & 103.3 & 3.5 & 30.7 & 8.1 & 2.2 & 154.8 & 3.6 & 0.76 \\
N.A558 & 233.3 & 162.8 & 7.3 & 35.8 & 11.4 & 3.1 & 284.0 & 2.9 & 0.77 \\
N.A432 & 206.2 & 144.5 & 2.9 & 38.7 & 9.4 & 2.5 & 229.7 & 3.8 & 0.77 \\
LSD 0.05 & 34.73 & 32.7 & 1.7 & 5.6 & 1.96 & 0.31 & 34.6 & 0.24 & NS \\
Mean士 SE & $206.6 \pm 16.87$ & $135.4 \pm 16.0$ & $5.7 \pm 0.85$ & $35.8 \pm 2.76$ & $10.3 \pm 0.95$ & $2.6 \pm 0.15210 .6 \pm 16.75$ & $3.3 \pm 0.12$ & $0.75 \pm 0.04$ \\
range & $167.2-233.3$ & $101.7-162.8$ & $1.3-7.7$ & $30.5-42.0$ & $8.1-12.2$ & $2.2-3.1$ & $154.8-284.0$ & $2.9-3.8$ & $0.68-0.78$ \\
\hline
\end{tabular}

the shortest one. Stem thicknes ranged from 2.2 to $3.1 \mathrm{~cm}$. N.A $\mathrm{A}_{558}$ had greatest value of stem thicknes, while, N.A 542 showing lowest value of stem thickness. Moreover for number of capsules/plant, N.A 558 recorded greatest number of capsules, while, N.A $A_{542}$ recorded the lowest one. Furthermore, capsule lenght varied from $2.9 \mathrm{~cm}$ for $\mathrm{N} . \mathrm{A}_{558}$ to $3.8 \mathrm{~cm}$ for $\mathrm{N} . \mathrm{A}_{432}$. The range for capsule thicknes was from 0.68 to $0.78 \mathrm{~cm}$ with mean of $0.75 \mathrm{~cm}$.

\section{Yield and Yield Attributes}

Results presented in Table 4 shows mean performance and range for yield traits i.e. seed yield/plant, seed index, seed yield/fad., and oil yield/fad., of eleven sesame genotypes over two years. It was obvious that the range for seed yield/plant was from 18.97 to $43.42 \mathrm{~g}$.N.A $\mathrm{A}_{558}$ recorded the highest yield $(43.42 \mathrm{~g})$ followed by line $89-26$ (37.63g). They were highly significantly higher yieling than the commercial cultivar Shandawell 3 by $112.5 \%$ and $84.19 \%$, respectively. Significant and differences has been registered in seed index among eleven sesame genotypes over the two years (Table 4), N.A $A_{558}$ had the heaviest value of seed index $(4.84 \mathrm{~g})$, meanwhile, shandwell 3 recoded the lowest $(3.47 \mathrm{~g})$ seed index. Regarding seed yield/ fad., the maximum seed yield/fad., was obtained from Line 89-26 (9.71 ard/fad.) followed by N.A ${ }_{558}(9.29 \mathrm{ard} / \mathrm{fad}$.$) . Both genotypes were$ higher than commercial cultivar shandwell 3 (5.36 ard/fad.) over the two years by 1.7 and 1.6 respectively. Five genotypes i.e. Line 88-2, Line 89-26, Line 82-7, N.A $\mathrm{A}_{558}$ and N.A $\mathrm{A}_{432}$ were higher than mean value $23.8 \%, 33.1 \%, 9.7 \%, 27.3 \%$ and $14.7 \%$, respectively. Also, Table 4 show significant differences in oil yield/fad., among eleven sesame genotypes over two years. N.A $\mathrm{A}_{558}$ recorded the greatest value of oil yield/fad., $(717.7 \mathrm{~kg})$, while N.A ${ }_{542}$ was the lowest oil yield/fad., $(293.8 \mathrm{~kg})$.

\section{Germination traits}

Mean performance in standared germination (\%), seedling lenght, redical lenght, shoot length, seedling vigor and seedling dry weight are presented in Table 5. Standared germination percentage of seeds had significant differences among the studied genotypes. The line 106-2 recorded the highest value of germination $(97.7 \%)$ with no significant difference with N.A $A_{542}$, N.A $A_{558}$, Line 88-2, Line 111-8 and Line 89-26. Meanwhile, the lowest germination percentage was $93.7 \%$ in 
Mourad, et al.

Table 4. Mean performance and range for yield traits for eleven genotypes (over two years)

\begin{tabular}{lcccc}
\hline Genotype & $\begin{array}{c}\text { Seed index } \\
(\mathbf{g})\end{array}$ & $\begin{array}{c}\text { Seed yield/plant } \\
(\mathbf{g})\end{array}$ & $\begin{array}{c}\text { Seed yield/fad. } \\
\text { (ardap) }\end{array}$ & $\begin{array}{c}\text { Oil yield/fad. } \\
(\mathbf{k g})\end{array}$ \\
\hline Shandwell 3 & 3.47 & 20.43 & 5.36 & 347.9 \\
Line 88-8 & 4.28 & 35.09 & 9.04 & 582.1 \\
N.A554 & 3.71 & 21.30 & 5.59 & 365.8 \\
Line 59-3-1 & 4.29 & 27.28 & 7.16 & 452.9 \\
Line 89-26 & 4.20 & 37.63 & 9.71 & 604.6 \\
Line 106-2 & 3.85 & 23.57 & 6.19 & 391.6 \\
Line 82-7 & 4.81 & 30.52 & 8.01 & 507.5 \\
Line 111-8 & 4.11 & 25.37 & 6.66 & 413.2 \\
N.A542 & 3.90 & 18.97 & 4.98 & 293.8 \\
N.A558 & 4.84 & 43.42 & 9.29 & 717.7 \\
N.A432 & 3.62 & 31.90 & 8.37 & 533.8 \\
L.S.D0.05 & 0.22 & 4.42 & 1.13 & 71.88 \\
Mean \pm S.E & $4.10 \pm 0.11$ & $28.68 \pm 2.15$ & $7.31 \pm 0,31$ & $473.7 \pm 19.23$ \\
Range & $3.47-4.84$ & $18.97-43.42$ & $4.98-9.71$ & $293.8-717.7$ \\
\hline
\end{tabular}

Table 5. Mean performance and range for seedling traits for eleven genotypes (over two years)

\begin{tabular}{|c|c|c|c|c|c|c|}
\hline Genotype & $\begin{array}{c}\text { Standard } \\
\text { germination } \\
(\%)\end{array}$ & $\begin{array}{l}\text { Seedling } \\
\text { length } \\
\text { (cm) }\end{array}$ & $\begin{array}{c}\text { Radical } \\
\text { length } \\
\text { (cm) }\end{array}$ & $\begin{array}{l}\text { Shoot } \\
\text { length } \\
\text { (cm) }\end{array}$ & $\begin{array}{c}\text { Seedling } \\
\text { vigor }\end{array}$ & $\begin{array}{l}\text { Seedling dry } \\
\text { weight } \\
\text { (mg) }\end{array}$ \\
\hline Shandwell 3 & 94.7 & 7.54 & 4.79 & 2.75 & 713.8 & 4.18 \\
\hline Line 88-2 & 96.6 & 8.18 & 5.42 & 2.77 & 790.2 & 3.52 \\
\hline N.A $\mathbf{A}_{54}$ & 95.3 & 9.60 & 6.34 & 3.27 & 914.7 & 3.77 \\
\hline Line 59-3-1 & 96.8 & 8.49 & 5.68 & 2.81 & 821.6 & 3.53 \\
\hline Line 89-26 & 96.1 & 8.46 & 5.43 & 3.03 & 813.3 & 4.44 \\
\hline Line 106-2 & 97.7 & 7.33 & 4.54 & 2.79 & 715.9 & 4.59 \\
\hline Line 82-7 & 95.8 & 8.82 & 5.44 & 3.38 & 845.2 & 3.49 \\
\hline Line 111-8 & 96.3 & 8.46 & 5.53 & 2.93 & 815.0 & 3.53 \\
\hline $\mathbf{N A}_{542}$ & 97.6 & 8.11 & 5.38 & 2.74 & 791.7 & 4.27 \\
\hline $\mathbf{N A}_{432}$ & 97.5 & 9.33 & 6.16 & 3.16 & 909.4 & 3.65 \\
\hline $\mathbf{N A}_{558}$ & 93.7 & 8.26 & 5.44 & 2.82 & 773.2 & 4.53 \\
\hline LSD 0.05 & 2.02 & 0.96 & 0.54 & 0.35 & 69.39 & 0.38 \\
\hline $\operatorname{Mean} \pm \mathbf{S E}$ & $96.2 \pm 0.99$ & $8.42 \pm 0.33$ & $5.47 \pm 0.26$ & $2.95 \pm 0.17$ & $809.5 \pm 29.39$ & $3.95 \pm 0.18$ \\
\hline Range & $93.7-97.7$ & $7.33-9.60$ & $4.54-6.34$ & $2.75-3.38$ & $713.8-914.7$ & $3.49-4.59$ \\
\hline
\end{tabular}


$\mathrm{NA}_{558}$ without significant differenc with Shandawell 3. Seedling length significantly varied across the two years. It ranged from 7.33 to $9.6 \mathrm{~cm}$ with a mean of $8.42 \mathrm{~cm}$. The genotype $\mathrm{NA}_{554}$ gave the highest value of seedling length. Range for radical length was from 4.54 to 6.34 with a mean of $5.47 \mathrm{~cm}$. The longest radical length was observed from $\mathrm{NA}_{554}$ followed by $\mathrm{NA}_{558}$, while, Line 106-2 had the shortest one. Shoot length varied from 2.75 to $3.38 \mathrm{~cm}$ across the two years. Line 82-7 was the longest shoot length (3.38), whereas, Shandawell 3 was the shortest length $(2.75 \mathrm{~cm})$. N.A $\mathrm{A}_{554}$ recorded the highest seedling vigor (914.7) followed by $\mathrm{NA}_{432}$ (909.4) with no significant differences between them, meanwhile, Shandawell 3 had the lowest seedling vigor (713.8). Line106-2 followed by $\mathrm{NA}_{559}$ had significantly highest seedling dry weight over two seasons. Othewise, Line 82-7 recorded the lowest seedling dry weight.

\section{Chemical composition}

Results in Table 6 illustrates that chemical composition of eleven sesame seeds genotypes was significantly affected by genetic makeup. Range for crude oil was $49.15-54.53 \%$. $\mathrm{NA}_{554}$ followed by Shandwell 3 had the greatest crude oil value, while, $\mathrm{NA}_{542}$ produced the lowest crude oil (49.15) across the two years. The crude protein ranged between $(21.68 \%$ ) for Line 106-2 to $(25.78 \%)$ for $\mathrm{NA}_{542}$ with a mean of $23.23 \%$. With respect to total carbohydrates, it ranged from $11.20 \%$ to $13.10 \%$, Line $89-26$ had the highest value being (13.10\%), while, $\mathrm{NA}_{554}$ and $\mathrm{NA}_{432}$ had the lowest value $11.2 \%$ and $11.21 \%$, respectively.

\section{Genetic parameters}

Component of genetic variance $\left(\sigma_{q}^{2}\right)$, phenotypic variance $\left(\sigma_{\mathrm{p}}^{2}\right)$ and environmental variance $\left(\sigma_{\mathrm{e}}^{2}\right)$, genetic variability (genotypic (GVC) and phenotypic (PCV) coefficient of variability, broad sense heritability, expected genetic advance (GC) and expected genetic advance under $5 \%$ selection intensity as percentage of the general mean (GS\%) for yield and some agronomic traits of eleven sesame genotypes are presented in Table 7. The phenotypic variance $\left(\sigma_{\mathrm{p}}^{2}\right)$ was greater than the corresponding genotypic variance for all studied traits except capsule thickness. The genotypic variance and phenotypic variance value for number of capsules/plant and oil yield/fad., were high over the two years. Similar results were obtained by Babu et al. (2005), Kumar and Sasivannan (2006), El-Shakhess et al. (2008), Ahmed et al. (2013) and Abate et al. (2015). The phenotypic coefficient of variance (PCV) was greater than genotypic coefficient of variance $(\mathrm{GCV})$ for all traits, indicating the influence of this trait by environmental modifications and the lower scope of improving these traits through selection. Number of capsules/plant and oil yield/fad., exhibited high estimates of GCV and PCV. The GCV for number of capsules/plant and oil yield/fad., were 43.4 and 579.57, suggesting wide spectrum of genotypic variation for these traits. The GCV and PCV were nearly equal for stem thickness, capsule length, capsule thickness, seed index and seed yield/fad., indicating that negliable influence of environment and improving such traits by selection will be effective. Meanwhile, low magnitude GCV and PCV were observed for number of branches/plant, number of nods/plant, internod length, stem thickness, capsule length, capsule thickness, seed index and seed yield/fad., suggesting minimal influence of environment on the expression of the traits so that it is easy to improve the previous traits based on the phenotypes. Besides traits such as, plant height, length of fruiting zone and seed yield/plant, they exhibited moderate estimates of PCV and GCV. These results are in harmony with those obtained by Iwo et al (2007), El-Shakhess et al (2008), Spandana et al (2011), Revathi et al (2012), Ahmed et al (2013), Bharathi et al (2014), Abate et al (2015), Swapa et al (2016) and Spandana et al (2016), High heritability was exhibited for plant height, length of fruiting zone, number of branches/plant, No of nods/ plant, internod length, stem thickness, number of capsules/plant, capsule length, seed yield/ plant, seed index, seed yield/fad., and oil yield/ fad. The findings are in harmony with those obtained by El-Shakhess et al. (2008), Alake $\boldsymbol{e t}$ al (2010), Jadhav and Mohrir (2013), Abate et al (2015) and Swapa et al. (2016). Only capsule thickness exihibited (0.0) heritability. Allard (1960) reported that hertability depends upon the amount of genetic variation presented in the population and environemental conditions under which the population is evaluated. Hertability 
Table 6. Chemical composition of eleven sesame genotypes (over two years)

\begin{tabular}{|c|c|c|c|}
\hline Genotype & Oil (\%) & Crude protien (\%) & Total carbohydrate $(\%)$ \\
\hline Shandwell 3 & 54.07 & 23.60 & 11.67 \\
\hline Line 88-2 & 52.65 & 21.78 & 13.10 \\
\hline N.A. $\mathbf{5 5 4}_{54}$ & 54.53 & 23.56 & 11.20 \\
\hline Line 59-3-1 & 52.70 & 22.70 & 12.43 \\
\hline Line 89-26 & 51.01 & 23.78 & 13.10 \\
\hline Line 106-2 & 52.75 & 21.68 & 12.85 \\
\hline Line 82-7 & 52.80 & 23.33 & 11.83 \\
\hline Line 111-8 & 51.72 & 23.74 & 12.35 \\
\hline $\mathbf{N A}_{542}$ & 49.15 & 25.78 & 12.16 \\
\hline $\mathbf{N A}_{558}$ & 52.50 & 22.08 & 12.87 \\
\hline $\mathbf{N A}_{432}$ & 53.13 & 23.45 & 11.21 \\
\hline LSD 0.05 & 0.79 & 0.76 & 0.72 \\
\hline Mean & 52.46 & 23.23 & 12.25 \\
\hline Range & $49.15-54.53$ & $21.68-25.78$ & $11.20-13.10$ \\
\hline
\end{tabular}

Table 7. Estimates of component of variance heritability and genetic advance for yield and agronomic traits of eleven sesame genotypes (over two years)

\begin{tabular}{lcccccccc}
\hline Trait & \multicolumn{2}{c}{ Component of variance } & \multicolumn{2}{c}{ Genetic variability } & \multicolumn{2}{c}{ Genetic advance } \\
\cline { 2 - 10 } & $\boldsymbol{\sigma}_{{ }_{9}}^{2}$ & $\boldsymbol{\sigma}_{\mathbf{e}}^{2}$ & $\boldsymbol{\sigma}_{\mathrm{pp}}^{2}$ & $\mathbf{G C V}$ & $\mathbf{P C V}$ & $\begin{array}{c}\mathbf{h}_{\mathbf{b}}^{2} \\
\mathbf{( \% )}\end{array}$ & $\begin{array}{c}\text { GC at } \\
\mathbf{5 \%}\end{array}$ & $\begin{array}{c}\text { GS as (\%) } \\
\text { of mean }\end{array}$ \\
\hline Plant height & 327.33 & 147.67 & 475.00 & 28.23 & 194.48 & 68.91 & 33.66 & 16.30 \\
Length of fruiting zone & 238.86 & 131.2 & 370.06 & 79.48 & 174.03 & 64.55 & 25.58 & 18.89 \\
No. of branches/plant & 3.25 & 0.37 & 3.62 & 20.08 & 26.35 & 89.78 & 3.61 & 63.40 \\
No. of nods/plant & 11.06 & 3.86 & 14.92 & 4.76 & 41.68 & 74.12 & 5.90 & 16.47 \\
Inter nod length & 1.51 & 0.47 & 2.08 & 0.39 & 20.19 & 72.59 & 2.30 & 22.32 \\
Stem thichnesed & 0.07 & 0.01 & 0.09 & 7.34 & 3.24 & 77.78 & 0.52 & 19.74 \\
No. of capsle/plant & 1194.36 & 420.69 & 1615.07 & 43.4 & 63.90 & 73.95 & 23.64 & 11.22 \\
Capsule length & 0.12 & 0.02 & 0.14 & 1.16 & 1.37 & 85.71 & 0.73 & 8.02 \\
Capsule thicknes & 0.00 & 0.00 & 0.00 & 0.00 & 0.10 & 0.00 & 0.00 & 0.07 \\
Seed yield/plant & 55.64 & 6.96 & 62.6 & 64.67 & 72.76 & 88.88 & 15.53 & 54.14 \\
Seed index & 0.19 & 0.07 & 0.21 & 1.55 & 1.69 & 90.45 & 0.90 & 21.94 \\
Seed yield/fad. & 1.18 & 0.14 & 1.32 & 9.25 & 10.38 & 89.39 & 22.62 & 61.75 \\
Oil yield/fad. & 4641.25 & 554.92 & 5196.17 & 579.57 & 648.86 & 89.32 & 37.71 & 10.31 \\
\hline
\end{tabular}


estimates coupled with the genetic advance would be more useful than heritability alone, because the estimates of heritability (broad sense) alone is not very much useful in predicting effect for selecting best genotypes because it includes both additive as well as non- additive gene effects. A high genetic advance occurs only due to additive gene action (Panse, 1957).

High broad- sense heritability accompanied with high genetic advance was recorded for No. of branches/plant, seed yield/plant and seedyield/ fad., indicated leser influence of environment in expression of these traits. The high heritability associated with low genetic advance expressed as percentage of mean were shown in plant height, length of fruiting zone, No. of nods/ plant, internod length, stem thickness, No. of capsule/plant, capsule length, seed index and oil yield/plant, suggested that these traits were controlled by high genotype environment interaction. In such situation, selection would not be rewording. Similar results were reported by El-Shakhess et al. (2008) Paramesh Warappa et al. (2009). Alake et al. (2010), Revathi et al. (2012), Ahmed et al. (2013), Jadhav and Mohrir (2013), Bharath et al. (2014), Abate et al. (2015), Gadisa et al. (2015) and Swapa et al. (2016). Estimation of component of variance, $\mathrm{GCV}$ and $\mathrm{PCV}, \mathrm{h}_{\mathrm{b}}{ }_{\mathrm{b}}$ and GA (\%) for germination and chemical traits over two years are presented in Table 8. phenotypic variance was greater than genotypic one for all traits. These results are in confirmatory with these of Iwo et al (2007), El-Shakhess et al. (2008) and Ahmed et al. (2013). Phenotypic coefficient variation (PCV) values were higher than genotypic coefficient of variation values for standard germination (\%), seedling length, radical length, seedling vigor, seedling dry weight and crude protein $(\%)$ indicating sensitivity of most of these traits to environmental modification and the lower scope of improving them through selection. On the other hand, the values of GCV were higher than values of PCV for shoot length, crude oil (\%) and total carbohydrate, indicating that those traits were not affected by environmental conditions. Broad sense heritability was high for all studied traits. The expected genetic advance ranged from $2.28 \%$ for standard germination to $22.31 \%$ for seedling dry weight. These results are in confirmatory with those of El-Shakhess et al. (2008) and Ahmed et al. (2013).

\section{Molecular Marker Combined Analyses for Eleven Sesame Genotypes}

In the present study five primers of SSR were selected to recognize between eleven genotypes of sesame. These primers produce multiple bands, which ranged between seven bands for primer SSR 5, to two bands for primer SSR2 and SSR3. The total number of bands was 19,10 of them were polymorphic (53\% polymorphism). The highest level of polymorphism was observed in primer SSR1 which showed 80\% polymorphism, while the lowest of polymorphism was $0 \%$ polymorphism in primer SSR2 and SSR3 as show in Table 9 and Fig. 1. Primer SSR1 produced 5 bands, 4 of them were polymorphic $(80 \%$ polymorphism). This primer SSR1 produced negative makers in two different genotypes, $\mathrm{NA}_{554}$ and Line 59-3-1. Primer SSR 2 generated 2 bands with $0 \%$ polymorphism, also SSR 3 gave the same results. Primer SSR 4 revealed 3 bands one of them was polymorphic with (33\% polymorphism). Primer SSR5 showed 7 bands, 5 of them were polymorphic (71\% polymorphism). This primer (SSR5) produced two makers for two different genotypes Line 59-3-1 and Line 82-7.

SSR markers can produce different markers at different three genotypes from eleven genotypes under study, two of them were positive bands and two of them were negative bands. $\mathrm{NA}_{554}$ showed one negative band marker in primer SSR 1 at molecular weight (MW) 295bp, also Line 59-3-1produced one negative marker in the same primer SSR 1 at MW 165 bp, while Line 59-3-1 produced one positive marker in primer SSR 5 at WM 180 bp. Line 827 showed one band positive marker in primer SSR 5 at MW $120 \mathrm{bp}$. Also Line 106-2 and Line 82-7 produced one positive band in MW at 120 bp in primer SSR 1, in the same way the N.A ${ }_{554}$ and Line 59-3-1 produced one positive band at MW 435 bp in primer SSR 5. Wu et al. (2014) suggested that domestication along with advanced plant breeding techniques have likely narredgeed the genetic basis of cultivated sesame. Mange newly developed sesame varieties were bred with a few number of landrace in their pedigree. The genetic variation in sesame was consequently reduced by genetic drift and selection characterization of genetic diversity of available landraces especially the indigenous and exotic collection by molecular markers is of 
Table 8. Estimates of component of variance, genotypic (GCV) and phenotypic (PCV) coefficients of variation broad sense heritability estimates $\left(h^{2}{ }_{b} \%\right)$ and genetic advance for germination and chemical traits of eleven sesame genotypes (over two years)

\begin{tabular}{|c|c|c|c|c|c|c|c|c|}
\hline \multirow[t]{2}{*}{ Trait } & \multicolumn{5}{|c|}{ Component of variance Genetic variability } & \multirow{2}{*}{$\begin{array}{l}\mathbf{h}^{2}{ }_{\mathrm{b}} \\
(\mathbf{\%})\end{array}$} & \multicolumn{2}{|c|}{ Genetic variability } \\
\hline & $\sigma_{9}^{2}$ & $\sigma_{\mathrm{e}}^{2}$ & $\sigma_{\mathrm{ph}}^{2}$ & GCV & PCV & & GS & GS (\%) \\
\hline Standard germination $(\%)$ & 1.34 & 0.51 & 1.85 & 0.02 & 1.66 & 72.43 & 2.19 & 2.28 \\
\hline Seedling length & 0.41 & 0.06 & 0.47 & 0.29 & 5.23 & 87.23 & 1.26 & 15.15 \\
\hline Radical length & 0.24 & 0.04 & 0.28 & 0.05 & 4.75 & 85.71 & 0.98 & 17.89 \\
\hline Shoot length & 0.04 & 0.01 & 0.06 & 4.34 & 1.68 & 66.67 & 0.39 & 13.24 \\
\hline Seedling vigor & 3857.6 & 589.4 & 4447 & 5.34 & 51.95 & 86.75 & 123.3 & 15.23 \\
\hline Seedling dry weight & 0.19 & 0.02 & 0.21 & 0.04 & 5.06 & 90.48 & 0.88 & 22.31 \\
\hline Crude oil (\%) & 1.97 & 0.08 & 2.05 & 6.34 & 3.84 & 96.10 & 2.87 & 5.47 \\
\hline Crude protein (\%) & 1.3 & 0.07 & 1.37 & 0.05 & 5.75 & 94.90 & 2.32 & 9.98 \\
\hline Total carbohydrate (\%) & 0.41 & 0.06 & 0.48 & 7.34 & 3.65 & 85.40 & 1.28 & 10.44 \\
\hline
\end{tabular}

Table 9. DNA polymorphic in eleven sesame genotypes using RCR with five SSR primers

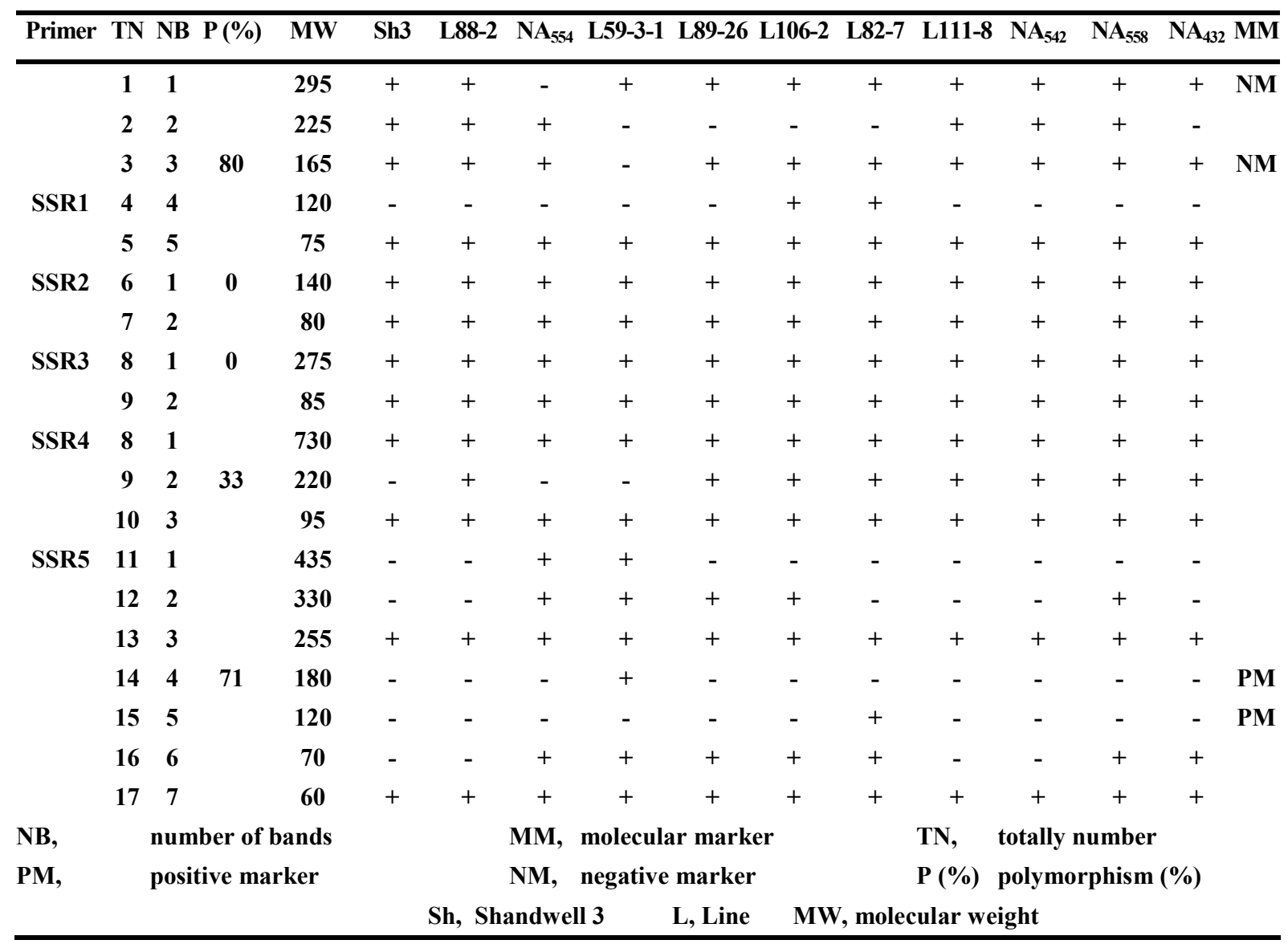


Zagazig J. Agric. Res., Vol. 46 No. (2) 2019

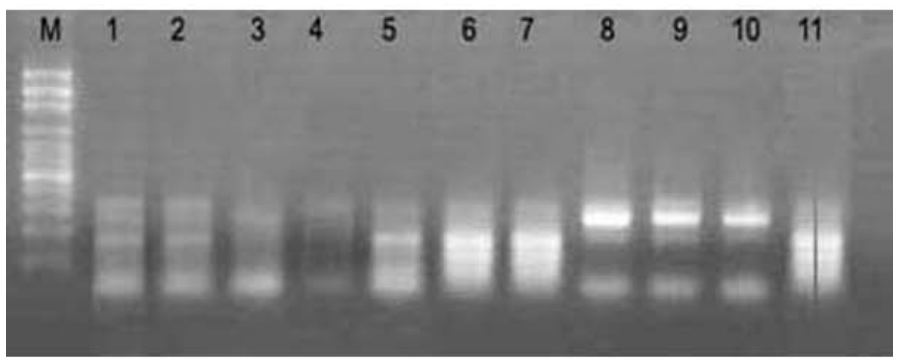

SSR 1

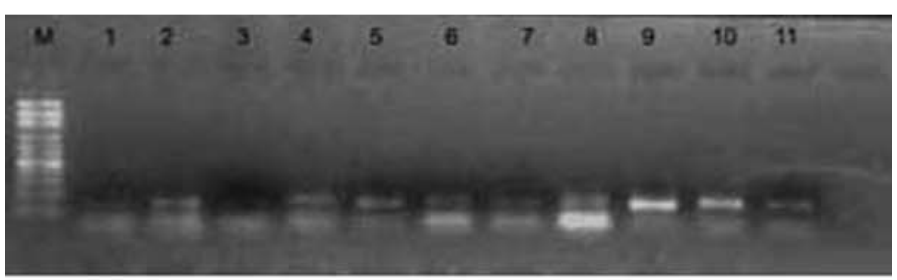

SSR 2

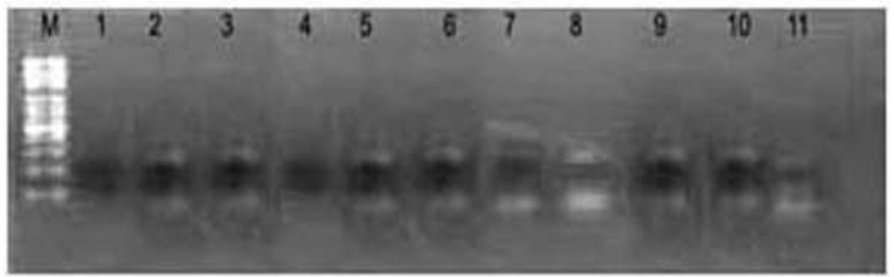

SSR 3

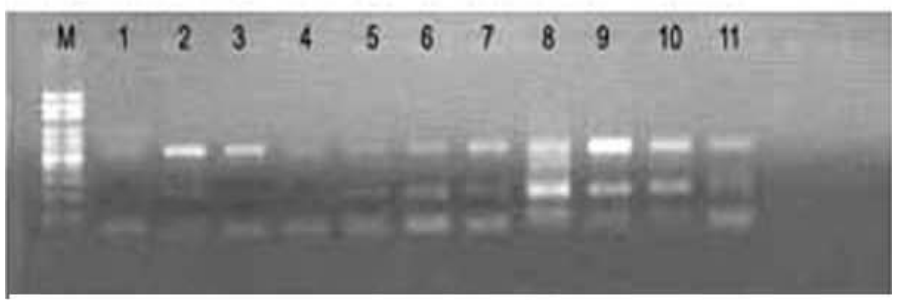

SSR 4

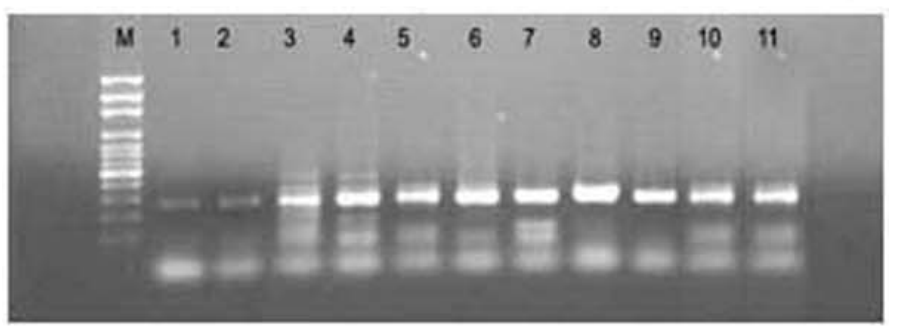

SSR 5

M- Molecular marker, 1- Shandwell 3, 2- Line 88-2,3- N.A ${ }_{554}, 4$ - Line 59-3-1, 5- Line 89-26, 6-Line 106-2, 7 Line 82-7, 8-N.A 542 , 9- Line 111-8, 10-N.A $558,11-$ N.A 432

Fig. 1. SSR banding patterns amplified with 5 primers 
great value to assist parentally design line selection and breeding strategy. Zhang et al. (2012) concluded that molecular markers are useful tool for detecting the genetic diversity, assessment genetic linkage map construction as well as marker assisted selection in sesame breeding programs.

\section{Combined Analysis for Eleven Sesame Genotypes}

Similarity index and dendrogram across the eleven sesame genotypes under investigation based on SSR analyses are shown in Table 10 and Fig. 2. The comparison revealed that the most closely related genotypes were Shandwell 3/ Line88-2, Shandwell 3/ Line111-8, Shandwell 3/ $\mathrm{NA}_{542}$, Line 88-2/Line111-8, Line 88-2/ $\mathrm{NA}_{542}$ and Line $111-8 / \mathrm{NA}_{542}$ (similarity matrix of 1 ).
The lowest relationships were recorded for genotype Shandwell 3/Line59-3-1, NA S42 $_{2}$ Line 59-3-1, Line59-3-1/Line111-2 and Line59-3$1 / \mathrm{NA}_{542}$ (similarity matrix of 0.786 ). Genomic SSR and expressed sequence tag (EST)-SSR, which are considered complementary to plant genome mapping, have been reported in several primary oil crops such as peanut (Hopkins $\boldsymbol{e t}$ al., 1999) and soybean (Akkaya et al., 1992) few EST-SSR were developed and used to detect genetic diversity for sesame germplasm (Wie et al., 2008; Wei et al., 2011; Zhang et al., 2012), however their use is limited due to relatively low polymorphism and high possibility of no gene rich rejoins in the genome. In contrast, genomic SSR are highly polymorphic and tend to be widely distributed throughout the genome resulting in more accurate detection of genetic diversity.

Table 10 . Similarity matrix among the eleven sesame genotypes used SSR analyses

\begin{tabular}{|c|c|c|c|c|c|c|c|c|c|c|}
\hline Genotype & 1-Shandwell 3 & $\begin{array}{l}\text { Line } \\
88-2\end{array}$ & $\mathbf{N A}_{554}$ & $\begin{array}{c}\text { Line } \\
59-3-1\end{array}$ & $\begin{array}{c}\text { Line } \\
89-26\end{array}$ & $\begin{array}{c}\text { Line } \\
106-2\end{array}$ & $\begin{array}{l}\text { Line } \\
82-7\end{array}$ & $\mathbf{N A}_{542}$ & $\begin{array}{c}\text { Line } \\
111-8\end{array}$ & $\overline{\mathbf{N A}_{.558}}$ \\
\hline 2-Line 88-2 & 1.000 & & & & & & & & & \\
\hline 3-N.A 554 & 0.857 & 0.857 & & & & & & & & \\
\hline 4-Line 59-3-1 & 0.786 & 0.786 & 0.867 & & & & & & & \\
\hline 5-Line 89-26 & 0.889 & 0.889 & 0.897 & 0.897 & & & & & & \\
\hline 6-Line 106-2 & 0.857 & 0.857 & 0.867 & 0.867 & 0.966 & & & & & \\
\hline 7-Line 82-7 & 0.857 & 0.857 & 0.8 & 0.8 & 0.897 & 0.933 & & & & \\
\hline $8-\mathbf{N A}_{542}$ & 1.000 & 1.000 & 0.857 & 0.786 & 0.889 & 0.857 & 0.857 & & & \\
\hline 9-Line 111-8 & 1.000 & 1.000 & 0.857 & 0.786 & 0.889 & 0.857 & 0.857 & 1.000 & & \\
\hline $10-N A_{558}$ & 0.929 & 0.929 & 0.933 & 0.867 & 0.966 & 0.933 & 0.867 & 0.929 & 0.929 & \\
\hline $11-N A_{432}$ & 0.923 & 0.923 & 0.857 & 0.857 & 0.963 & 0.929 & 0.929 & 0.923 & 0.923 & 0.929 \\
\hline
\end{tabular}
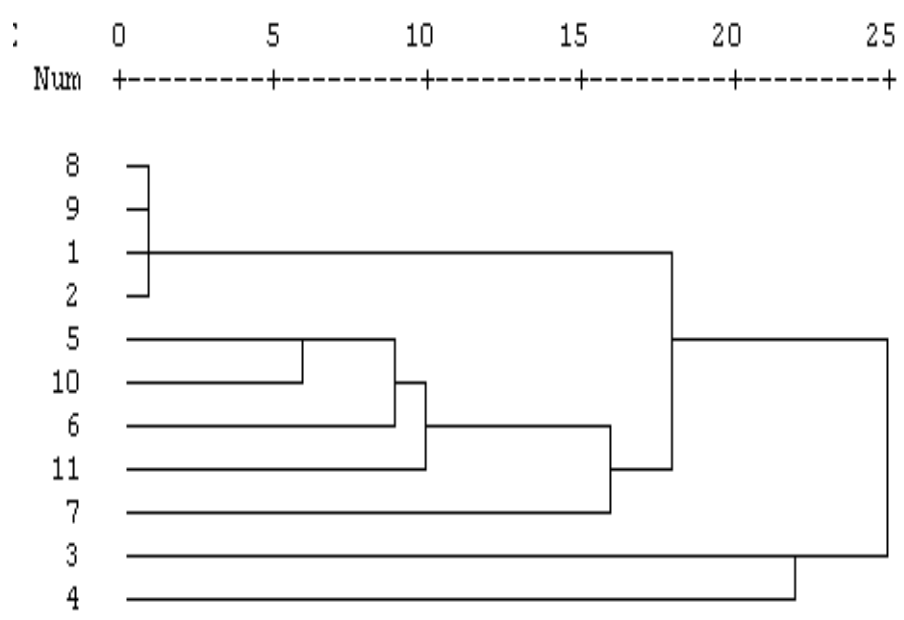

Genotypes names -1- Shandwell 3, 2- Line 88-2, 3- N.A ${ }_{554}$, 4- Line 59-3-1, 5- Line 89-26, 6-Line 106-2, 7-Line 82-7, 8-N.A $A_{542}, 9-$ Line $111-8,10-$ N.A $A_{558}, 11-$ N.A $A_{432}$

Fig. 2. Dendrogram of the genetic distances among the eleven sesame genotypes used SSR analyses 


\section{REFERENCES}

Abate, M., F. Mekbib, A.A. Ayana and M. Nigussie (2015). Genetic variability and association of traits in midaltitde sesame (Sesamum indicum L.). Germplasm of Ethiopia. Ame. J. Exp. Agril., 9 (3): 1-14.

Ahmed, F.H.A., A.M. Hassanein and I.S. ElDemardash (2013). Evaluation and genetic diversity of eleven sesame lines. Egypt. J. Genet .Cytol., 42 (1): 205-225.

Akkaya, M.S., A.A. Bhagwat and P.B. Cregan (1992). Length polymorphism of simple sequence repeat DNA in soybean Genet., 132: 1131-1139.

Alake, C.O., M.A. Vaughan and O.O. Ajani (2010). Estimated of variability for yield and its characters Nigerian sesame (Sesamum indicum L.) genotypes J. Agric. Sci. Env., 10 (1): 72-85.

Allared, R.W. (1960). Principles of Plant Breeding. Joh Wiley and Sons Inc. New York, 458.

AOAC (2000). Official Methods of Analysis of Association of Official Analytical Agricultural Chemists, $17^{\text {th }}$. Published by AOAC.

AOSA (1983). Seed Vigor Testing Handbook Contribution No.32 to Handbook on Seed Testing. Association of Official Seed Analysis, 88-93.

Babu, D.R., P.V.R. Kumar and C.V.D. Rani (2005). Genetic variability, heritability and genetic advance of seed yield and its components in sesame (Sesamum indicum $\mathrm{L}$.) Res. Crops-Gaurav Soc. Agric. Res. Inform. Cent., Hisar, Indias, 6: 307-308.

Banerjee, P.P and P.C. Kole (2006). Genetic variability for some physiological characters in sesame (Sesamum indicum L.). Sesame and Safflower News Letter, 21:20-24.

Bharathi, D., V. Thirumale Roa., Y. Chandra Mahan, D. Bhadru and V. Venkanna (2014). Genetic variability studies in sesame (Sesamum indicum L.). Int. J. Appl. Biol. and Phormacentical Technol., 5 (4): 31-33.

El-Shakhess, S.A.M., Y.M. Abdel-Tawab and N.A. Nagib (2008). Evaluation and differentiation of eleven sesame lines. Egypt. J. Plant Breed., 12:1-25.
Fazal, A.M., A. Rabbani, Z.K. Shinwari and S.J. Khan (2011). Genetic divergence in sesame (Sesamum indicum L.) Landraces based on qualitative and quantitative. POK. J. Bot., 43 (6): 2737-2744.

Gadisa, H., G. Nagash and J. Zerihun (2015). Genetic variability, heritability and genetic advance for phenotypic traits in sesame (Sesamum indicum L.), populations from Ethiopla. Sci. Technol. Arts Res. J., 4 (1): 20-26.

Hopkins, M.S., A.M. Casa, T. Wang, S.E. Mitchell, D.R.E. Kochert and G.D.S. Kresovich (1999). Discovery and characterization of polymorphic simple sequence repeats (SSRs) in peanut Crop Sci., 39: 1243-1247.

ISTA (1993). International Seed Testing Association. International Rules for Seed Testing Seed Sci. and Technol., 21:187-209.

ISTA (1985). International Seed Testing Association. International Rules for Seed Testing Proc. Int. Seed Test Assoe., 31:1-52.

Iwo, G.A., A.A. Idowu and S. Misari (2007). Genetic variability and correlation studies in sesame (Sesamum indicum L.). Global J. Pure and Appl. Sci. Bachudo Sciene Co. Lid., Calabar, Nigeria, 13: 35-38.

Jadhav, R.S. and M.N. Mohrir (2013). Estimation of genetic varability parmeters in sesame (Sesamum indicum L.). Int. J. Plant Sci., 8 (2): 280-283.

Krishnasamy, V. and D.V. Seshu (1990). Germination after accelerated ageing and associated characters in rice varieties seed Sci. Technol., 18:147-156.

Kumar, P.S. and S. Sasivannan (2006). Variability, heritability and genetic advance in sesame (Sesamum indicum L.). Crop Res., 31: 258-260.

Laurenthin, H.E. and P. Korlovsky (2006). Genetic relationship and divessity in sesame (Sesamum indicum L.) germplasm collection using amplified fragment length polymorphisim (AFLP). BM Genetics 1:10.

Mather, K. and J.L. Jinks (1982). Bionmetrical Genetics. $3^{\text {th }}$ Ed. Champman and Itall, Landon.

Miller P.A., J.C. Williams, H.F. Robinsan and R.F. Comatok (1958). Estimation of genotypic and environmental variances and 
covariance in upland cotton and their impilicationsin selection. Agron. J., 50: 126131.

Nupur, M., K.V. Bhat and P.S. Srivastava (2010). Variation in fatty acid composition in Indian germplasm sesame. J. Ame. Oil Chem. Soc., 87 (11): 1263-1269.

Panse, V.G. (1957). Genetic of quantitative characters in relation to plant breeding Indian J. Genet Breed, 17: 318-328.

Paramesh Warappa, S.G., M.G. Palakshappa, P.M. Salimath and K.G. Parmeshwaappa (2009). Studies on genetic variability and character association in germplas collection of sesame (Sesamum indicum L.). Karmatakor J. Agric. Sci., 22. (2): 252-254.

Park, J.H., S. Suresh, G.T. Cho, N.G. Choi, H.J. Baek, C.W. Lee and J.W. Chung (2013). Assessment of molecular genetic diversity and population structure of sesame (Sesamum indicium L.) core collection accessions using simple sequence repeat markers. Plant Genet Resour Charact Util., 1 (8): 1010 -1017

Powell, W., G.C. Machray and Jprovan (1996). Polymorphism revealed by simple sequence reppate. Trends Plant Sci., 1:215-223.

Revathi, S., A. Johujoet and N. Manivannan (2012). Genetic variability in sesame (Sesamum indicum L.) Electronic J. Plant Breed., 3 (1): 692-694.

Sambrook, J., E.F. Fritsch and T. Maniatis (1989). Molecular cloning. A Laboratory manual, Second

Singh, R.K. and B.D. Chaudhry (1985). Biometrical Methods in Quantitative Genetic Analysis-Kalyani Publisher New Delhi, 303.

Song, Q.J., L.F. Marek, R.C. Shoemaker, V.C. Lark, X. Concibido, X. Delannay, J.E. Specht and P.B. Cregan (2004). A new intereated genetic linkage map of the soybean. Theor Appl. Genet., 109: 122-128.

Spandana, B., V.P. Reddy, G.J. Prasanna, G. Anuradha and S. Sivaramakrishnan (2012). Development and characterization of microsatellite markers (SSR) in sesame (Sesamum indicum L.) species. Appl. Bioctechnol., 168: 1594-1607.
Spandana, B., A. Chanta, S. Natorajan and S. Subramonian (2016). Determination of genetic variability in Indian sesame (Sesamum indicum L.) genotypes for agromorphological traits. J. Res. Agric. Sci., 7 (2): 88-99.

Singh, R.K. and B.D. Chaudhry (1985). Biometrical Methods in Quantitative Genetic Analysis-Kalyani Publisher New Delhi, 303.

Surapaneni, M., V. Yepuri, R.L. Vemireddy, A. Ghanta and E.A. Siddiq (2014). Development and characterization of microsatellite markers in Indian sesame (Sesamum indicum L.). Mol Breed., 34 (3): 1185-1200.

Swapa, K., D.R.M. Triphathy, S. Shra, Panda, N. Senpati, P.K. Nayak, G.B. Dash, S.K. Mohonty, M.R. Mohanty, M. Jena and K. Prodham (2016). Assessment of genetic variability in sesame (Sesamum indicum L.). Asian J. Sci. and Technol., 7 (2): 2482-2485.

Wei, W., X. QI, L. Wang, Y. Zhang, W. Hua, D. $\mathrm{Li}, \mathrm{H}$. Lv and X. Zhang (2011). Characterization of thesesame (Sesamum indicum L.) global transcriptome using 1llumina paired-end Develop. EST-SSR Markers. BMC Gemomics, 12-451.

Wie, L.B., H.Y. Zhang, Y.Z. Zheng, W.Z. Guo and T.Z. Zhang (2008). Developing ESTderived mirrosatellite in sesame (Sesamum indicium L.). Acta. Agron. Sin, 34 : 20772084.

Wu, K., M. Yang, H. Liu, Y. Tao, J. Mei and Y. Zhano (2014). Genetic analysis and molecular characterization of Chinese sesame (Sesamum indicum L.) Cultivar susing in sertion-deleion (In Del) and sequence repeat (SSR) makers. BBC Genet., 15:35

Zhang, Y.X., X.R. Zhang, W. Hua, L.H. Wang and Z. Che (2010). Analysis of genetic diversity among indigenous landraces from sesame (Sesamum indicum L.) core collection in China as Revealed by SRAP and SSR Markers. Genes Genom., 32 3: 207-215.

Zhang, H., L. Wei, H. Miao, T. Zhang and C. Wang (2012). Development and validation of genic SSR markers in sesame by RNA seq. BMC Genomic., 13: 316. 


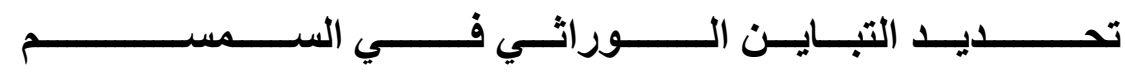

خميس عبد الجيد مراد' - رشا يوسف سبد عبد الخالق بـ نعمث عدلي نجيب؟

ـ قسم بحوث المحاصيل الزيتية ـ معهد بحوث المحاصيل الحقلية ـ مركز البحوث الزر اعية ـ الجيزة ـ مصر

Y ـ قسم بحوث تكنولوجيا البذور - معهد بحوث المحاصبل الحقلية ـ مركز البحوث الزر اعية ـ الجيزة ـ مصر

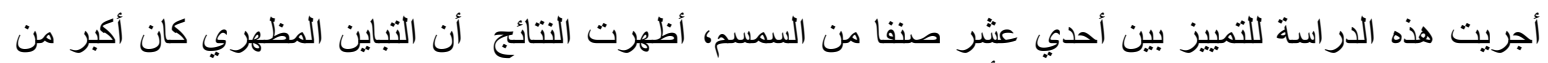

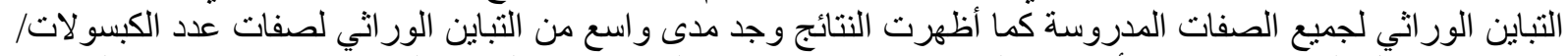

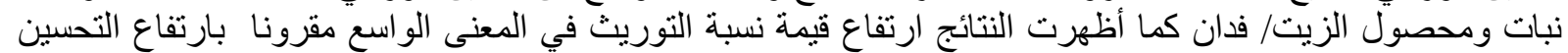

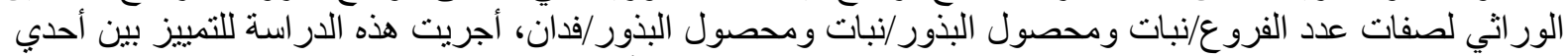

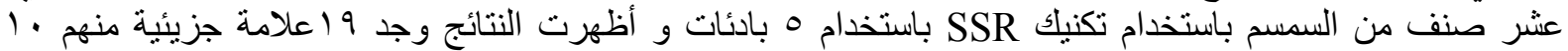

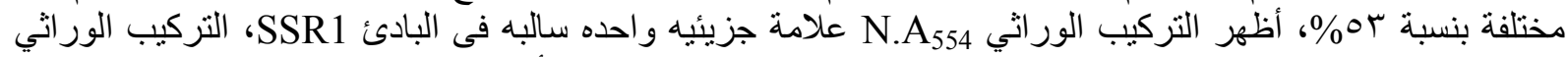

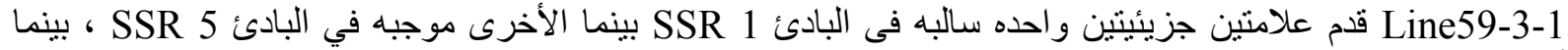

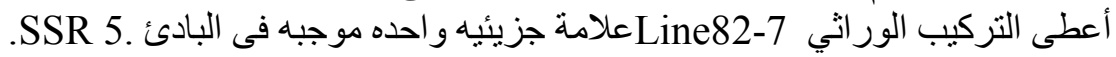

أستاذ المحاصيل المتفرغ - كلية التكنولوجيا والتنمية - جامعة الزقازيق. أستاذ ورئيس قسم المحاصيل ـ كلية الزر اعة - جامعة الزقازيق.

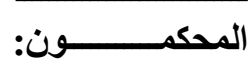

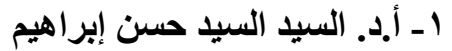

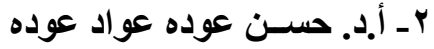

